Research

\title{
Spatiotemporal dynamics of glacial lakes (1990-2018) in the Kashmir Himalayas, India using Remote Sensing and GIS
}

\author{
Rayees Ahmed ${ }^{1}$ (D) . Gowhar Farooq Wani ${ }^{1}$ (D) . Syed Towseef Ahmad ${ }^{1}$ (D) $\cdot$ Riyaz Ahmad Mir $^{2} \cdot$ Mansour Almazroui $^{3,4}$. \\ Sanjay K. Jain ${ }^{5}$ Pervez Ahmed ${ }^{1}$ (D)
}

Received: 31 July 2021 / Accepted: 13 October 2021

Published online: 25 October 2021

(c) The Author(s) $2021 \quad$ OPEN

\begin{abstract}
This study is perhaps the first attempt to use satellite data (1990-2018) to analyze spatiotemporal changes in glacial lakes over the Kashmir Himalayas supplemented by field studies. Landsat images were used to delineate the spatial extent of glacial lakes at four-time points, i.e., 1990, 2000, 2010 and 2018. The total count of lakes as well as their spatial extent showed a discernible increase. The number increased from 253 in 1990 to 324 in 2018, with a growth rate of 21.4\%. The area has increased from $18.84 \pm 0.1 \mathrm{~km}^{2}$ in 1990 to $22.13 \pm 0.12 \mathrm{~km}^{2}$ in 2018 with a growth rate of $14.7 \%$. The newly formed glacial lakes, including supraglacial lakes, were greater in number than the lakes that disappeared over the study period. All glacial lakes are situated at elevations of $2700 \mathrm{~m}$ asl and $4500 \mathrm{~m}$ asl. More than $78 \%$ of lake expansion in the study region is largely due to the growth of existing glacial lakes. Through area change analysis, our findings reveal that certain lakes show rapid expansion needing immediate monitoring and observation. The analysis of the meteorological variables reveals that minimum and maximum temperatures in the Jhelum basin have shown an increasing trend. $T_{\text {max }}$ showed an increase of $1.25^{\circ} \mathrm{C}$, whereas $\mathrm{T}_{\min }$ increased to $0.7^{\circ} \mathrm{C}$ from 1980 to 2020 . On the other hand, precipitation has shown a decreasing trend, which can be attributed to one of the major causes of glacier recession and the expansion of glacial lakes in the Upper Jhelum basin. Consequently, this study could play a significant role in devising a comprehensive risk assessment plan for potential Glacial Lake Outburst Floods (GLOFs) and developing a mechanism for continuous monitoring and management of lakes in the study region.
\end{abstract}

Keywords Climate change · Glacial Lake expansion · Remote sensing · Landsat imageries · GLOFs · Kashmir Himalaya · India

\section{Introduction}

Glacial lakes are bodies of water strongly influenced by the presence of glaciers [1] and/or retreating processes of a glacier [2]. Globally, climate variability has a significant influence on the downwasting of glaciers $[3,4]$ as a result of forming new glacial lakes or increasing the spatial extent of existing lakes [5-8]. With shrinking Himalayan glaciers, the high-altitude

Pervez Ahmed, pervezahmeduok@gmail.com; Rayees Ahmed, rayeesrashid84@gmail.com; Gowhar Farooq Wani, gowhernaz@ gmail.com; Syed Towseef Ahmad, stawseef77@gmail.com; Riyaz Ahmad Mir, riyazgsi@gmail.com; Mansour Almazroui, mansour@ kau.edu.sa; Sanjay K. Jain, sjain.nihr@gov.in | 'Department of Geography and Disaster Management, School of Earth and Environmental Sciences, University of Kashmir, Srinagar 190 006, India. ${ }^{2}$ Geological Survey of India, UT: Jammu and Kashmir, Srinagar 190008, India. ${ }^{3}$ Center of Excellence for Climate Change Research/Department of Meteorology, King Abdulaziz University, PO Box 80208, Jeddah 21589, Saudi Arabia. ${ }^{4}$ Climate Research Unit, School of Environmental Sciences, University of East Angila, Norwich, UK. ${ }^{5}$ National Institute of Hydrology, Roorkee, India.

Discover Water $\quad$ (2021) 1:7 https://doi.org/10.1007/s43832-021-00007-1 
Table 1 Glacial Lake inventory studies in the Himalayan region

\begin{tabular}{lllllcl}
\hline S. No & Study by & Minimum size & Satellite/sensor/resolution & No of lakes & $\begin{array}{l}\text { Area of lakes } \\
\mathrm{km}^{2}\end{array}$ & Study region \\
\hline 1 & {$[73]$} & 0.0005 & Resourcesat-2 LISS IV/5 & 1266 & 7.59 & Uttarakhand \\
2 & {$[53]$} & 0.003 & Landsat TM/ETM+/30 & 2168 & 127.61 & Koshi basin \\
3 & {$[19]$} & 0.003 & Landsat TM/OLI & 1541 & 80.95 & Nepal Himalaya \\
4 & {$[18]$} & 0.01 & Resourcesat-2 LISS IV/5 & 147 & 5.12 & Himachal Pradesh \\
5 & {$[93]$} & 0.15 & Landsat TM/ETM+/OLI/30 & - & 37.9 & Central \& Eastern Himalaya \\
6 & {$[74]$} & 0.005 & Landsat TM/ETM+/OLI/30 & 30,121 & 2080.12 & High Mountain Asia \\
7 & {$[55]$} & 0.008 & Landsat TM/ETM+/OLI/30 & 15,348 & 1395.733 & High Mountain Asia \\
8 & Present study & 0.001 & Landsat TM/ETM+/OLI/30 & 322 & 22.11 & Kashmir Himalaya \\
\hline
\end{tabular}

lakes in the region are continuously evolving and growing in number and size [9-15]. Himalayan glacier recession is largely attributed to the impact of changing global climate [16-24] and topographic regimes [22]. The continuous shrinkage of glaciers, as reported in the Central Himalayas, could trigger glacial lake expansion in the future [19]. The accelerated rate of glacial lake expansion increases the risk of outbursts of glacial lakes [25-28]. Furthermore, the development of dangerous glacial lakes and the risk of outburst flooding in mountainous regions are unarguably critical concerns for South Asian countries (e.g., Nepal, China, Pakistan, Bhutan, and India) [29]. GLOF events pose a serious threat to nearby communities and built infrastructure [4, 30-32]. This was evident in the case of the 2014 Gaya GLOF event that caused destruction in terms of agricultural losses, damage to immediate infrastructure and channel defences, the major reason being the lake's potential to outburst and subsequent sudden downstream draining [33].

There have been several instances of GLOF events in the past striking the Himalayan region [30, 34-39]. The well documentation of such multiple extreme weather events acts as historic evidence to identify Himalayas as GLOF high-risk regions, e.g., Nare (Nepal) in 1977 [40]; Nagma Pokhari (Nepal) in 1980 [11, 41]; Zhangzangbo (Tibet) in 1981 [42, 43]; Dig Tsho in 1985 [44]; and Lugge Tsho (Bhutan) in 1994 [38, 45]. The recent event was an outburst flood that struck a village (Gaya) in Ladakh, India in 2014 [33]. Remote sensing has been largely a potent method for constant monitoring and timely detection of GLOFs over inaccessible mountain-bound regions, as it guides us to investigate a large area [46, 47].

To carry out an updated inventory and understanding the spatiotemporal dynamics of glacial lakes is the first important step for monitoring and assessing GLOFs in a region $[6,48,49]$. These multitemporal inventories serve as a baseline for studying the evolution, disappearance, and identification of potentially dangerous glacial lakes [50-52] as well as modelling GLOFs using various hydrodynamic models. In the Himalayan region, numerous inventories have been carried out by different authors according to their purpose of the study. For example, an inventory of 958 glacial lakes (size $>500 \mathrm{~m}^{2}$ ) for Himachal Pradesh (areal coverage $9.6 \pm 0.3 \mathrm{~km}^{2}$ ) using the LISS IV data [18], a multitemporal inventory of glacial lakes in the Central Himalayas using Landsat series of data [6], mapping of 2168 glacial lakes with area $127.61 \mathrm{~km}^{2}$ in Koshi basin of Central Himalayas [53], and an inventory of 1541 glacial lakes in the Nepal Himalayas with area $80.95 \pm 15.25 \mathrm{~km}^{2}$ [19]. Various studies that have focused on the inventories of glacial lakes in the Himalayan region are summarized in Table 1. However, to date, no exhaustive study has focused on the glacial lakes of the Jhelum Basin in particular, except for a few noteworthy studies $[30,54,55]$ that have mapped some of the glacial lakes in the upper Jhelum Basin of the Kashmir Himalayas. Thus, there has been a gap in knowledge over the most recent decades. With the geographic importance of the Jhelum Basin, an updated glacial lake inventory and an analysis of spatiotemporal dynamism are needed.

To address this need, in the current study, spatiotemporal changes in glacial lakes were observed through time series Landsat imageries of the Kashmir Himalaya from 1990 to 2018. Consequently, the results were linked to the changing climatic regimes and glacier recession to understand the influence of climate change and glacier fluctuations on the expansion of glacial lakes. This is a step towards better and continuous monitoring of lake expansion in the study area, which is critical for GLOF hazard mitigation. 


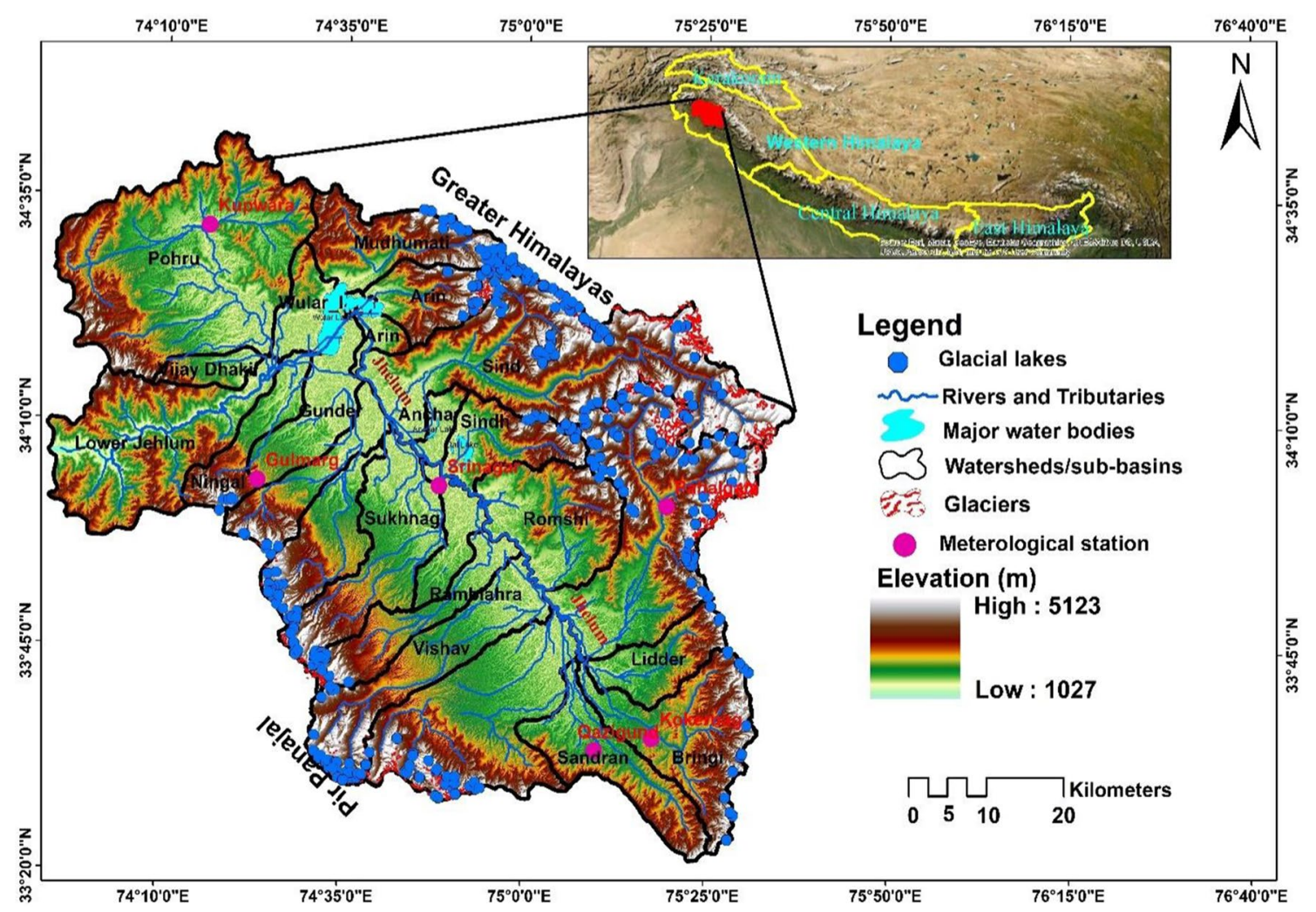

Fig. 1 Location map showing glacial lakes in the Kashmir Himalaya

\section{Study area}

Kashmir Valley is oval-shaped and has a dramatic landscape with several glaciers and glacial lakes spread over lofty mountains. Flanked by the Pir Panjal Mountains in the southwest and the Greater Himalayan range in the northeast, the study region (between $32^{\circ} 20^{\prime}-34^{\circ} 50^{\prime} \mathrm{N} \& 73^{\circ} 55^{\prime}-75^{\circ} 35^{\prime} \mathrm{E}$ ) is in the Union Territory of Jammu and Kashmir, India ${ }^{1,2}$ (Fig. 1). Kashmir Valley has an area of approximately 15,948 square kilometers ${ }^{3}$ [56]. Dar et al. [57] and Ahmed et al. [58] reported that the Pir Panjal range obstructs southwestern monsoons from entering the valley, shaping the climate of the Kashmir region to a more arid-windy type in comparison to the tropical type in other parts of India. Kashmir Valley experiences four seasons: spring, summer, autumn and winter) [59] with annual average precipitation and temperature, i.e., $710 \mathrm{~mm}$, $13.5^{\circ} \mathrm{C}$, while receiving enormous precipitation during winter months (December-February) due to western disturbances $[57,60]$. Lakes formed during the time of deglaciation preceded by cold conditions in the Kashmir Himalayas [61].

There are large reserves of glaciers and glacial lakes in North Kashmir that also contribute to the Jhelum River. Jhelum is one of the main tributaries of the Indus basin and acts as a lifeline to the Kashmir valley [22]. The altitude of the study area ranges from 1065 to $5441 \mathrm{~m}$ asl.

\footnotetext{
1 https://www.britannica.com/place/Vale-of-Kashmir.

2 https://en.wikipedia.org/wiki/Kashmir_Valley.

3 http://jkforest.gov.in/geo_area.html.
} 
Table 2 Satellite data used

\begin{tabular}{lllllll}
\hline Date of pass & Satellite \& sensor & $\begin{array}{l}\text { Bands \& wave- } \\
\text { length }(\mu \mathrm{m})\end{array}$ & path/row & $\begin{array}{l}\text { Spatial reso- } \\
\text { lution }(\mathrm{m})\end{array}$ & $\begin{array}{l}\text { Repeat } \\
\text { cycle (days) }\end{array}$ & Cloud cover \\
\hline 14 Oct. 1990 & Landsat TM & 6 & $149 / 36$ & 30 & 16 & No \\
09 Oct. 2000 & Landsat TM & 6 & $149 / 36$ & 30 & 16 & \\
18 Oct. 2010 & Landsat ETM+ & 8 & $149 / 36$ & 30 & 16 & \\
04 Oct. 2018 & Landsat L8 (OLI) & 9 & $149 / 36$ & 30 & 16 & \\
\hline
\end{tabular}

Thematic Mapper TM. Enhanced Thematic Mapper ETM. Operational Land imager OLI

\section{Methodology}

\subsection{Datasets}

Landsat data have been extensively utilized for the purpose of delineation and mapping glacial lakes due to their free availability, $30 \mathrm{~m}$ resolution and wide area coverage [62-65]. Landsat images of $30 \mathrm{~m}$ resolution and the Advanced Spaceborne Thermal Emission \& Reflection Radiometer-Digital Elevation Model (ASTER DEM, $30 \mathrm{~m}$ ) downloaded from the web portal were used in the present study (Table 2). The Landsat images hosted by the Global Land Survey (GLS) data system of the United States Geological Survey (USGS) were downloaded from their web portal ${ }^{4}$ and used for the current study. Glacial lakes show minor changes in the post-monsoon season with limited cloud and snow cover [66]. Landsat scenes used in the study were from the post-monsoon season with less cloud coverage $(<10 \%)$ or were cloud-free. The Landsat images from 1990 to 2018 were used to prepare glacial lake inventories for area change analysis. Validation of glacial lake boundaries for 1990 was performed using the Survey of India (SOI) toposheet 1979, Scale 1:50,000. The SOI toposheets alone are less reliable for change detection analysis [50]; hence, the Landsat TM (1990) scene has been used as a base image for glacial lake area change.

To validate the glacial lake outlines, Google Earth imagery of high resolution was used because of the comparatively coarser resolution of the Landsat data. The time series of meteorological data (e.g., temperature and precipitation) from 1980 to 2020 of the Pehalgam weather station was analysed to understand climate as a possible influencing factor for glacial lake changes in the study area.

\subsection{Glacial lake mapping}

A number of methods (processing satellite imagery) have been used for mapping glacial lakes over time. The two commonly used methods are automated and semiautomated methods, e.g., the normalized difference water index (NDWI) $[25,63,67-69]$. In the present study, we used the normalized difference water index NDWI-first proposed in 1996 by McFeeters [70] using a semiautomated method similar to [46] for delineation of glacial lake outlines (Fig. 2; Eq. 1).

$$
N D W I=\frac{B N I R-\text { Bblue }}{B N I R+\text { Bblue }}
$$

*BNIR and Bblue are reflectance in the near infrared and blue bands, respectively.

Pixel identification pertaining to the lakes was performed based on NDWI values in the range of -0.60 to -0.85 [48]. A few mountain-shadowed areas were mistaken as lakes due to the same spectral reflectance and topographic effects [19, 53]. Misclassification could occur due to near similarities between glacial lakes from frozen lakes and snow cover because of peculiar surface conditions. The pixels identified as mountain shadows were removed from ASTER DEM-derived values for slope, aspect and hill shade in NDWI images to overcome misclassification of lakes because of topographic effects.

Further correction was performed through a visual interpretation technique using ArcGIS 10.2 [19, 28, 49, 66, 71, 72]. Through this process, the first glacial lake layer in 2018 was prepared. The glacial lake outlines were overlaid with Google Earth imagery for validation and later crosschecked with the toposheet glacial lake inventory generated from SOI toposheet 1979 at a scale of 1:50,000. Corrections, if any, were taken on priority. Subsequently, glacial lake

\footnotetext{
4 www.earthexplorer.usgs.gov.
} 
Fig. 2 Flowchart showing the process of glacial lake mapping for area change detection

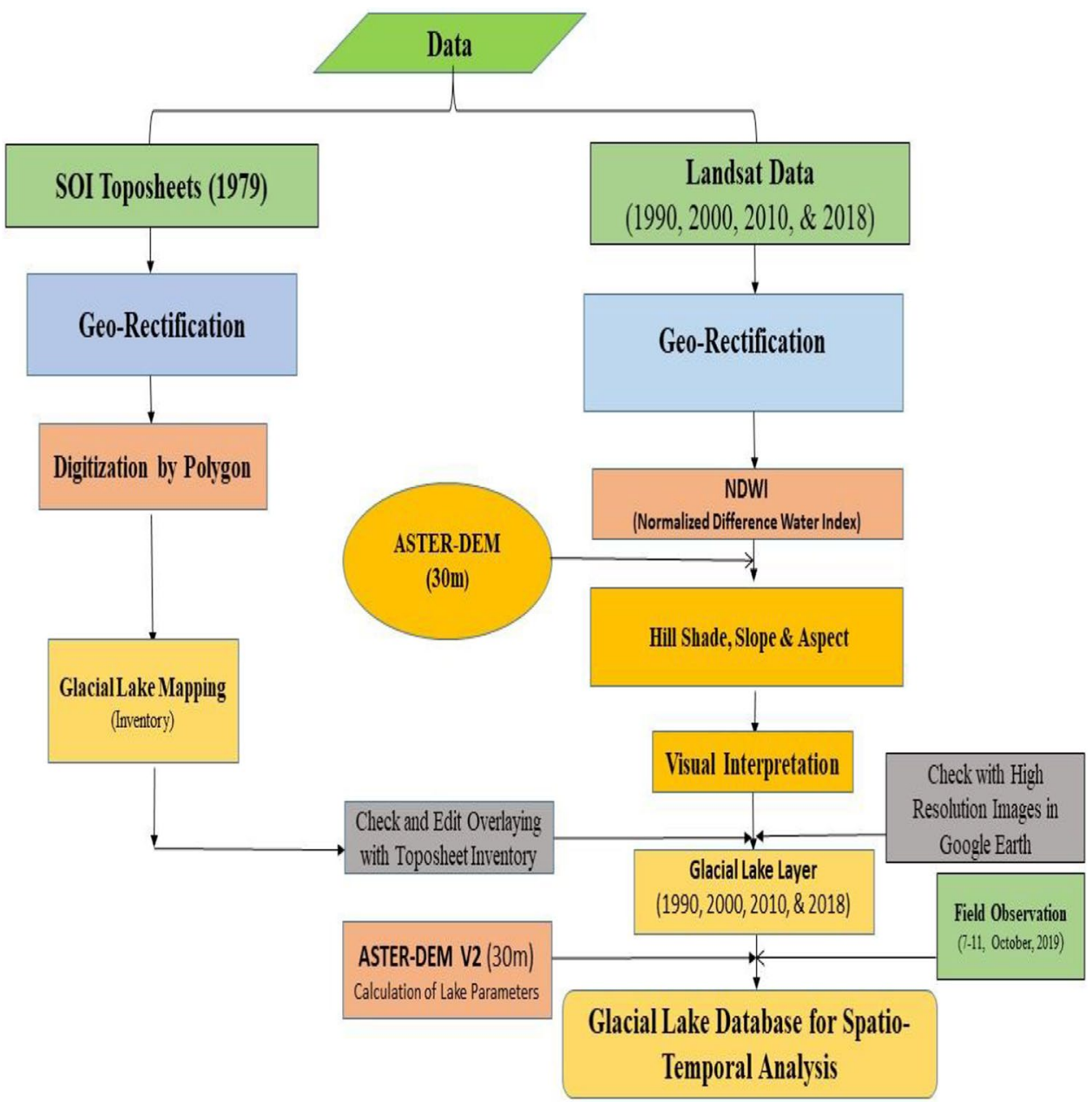

inventories for 2010, 2000 and 1990 were prepared to obtain the final database to observe glacial lake expansion in the study area (Fig. 2).

\subsection{Glacial lake classification}

Classification of glacial lakes plays an important role to know the location and to understand the origin and evolution of glacial lakes. Glacial lake characteristics which include phases of lake formation, constituents of dam material, glacier proximity, moraines, outwash plains and other geomorphological features should be taken into consideration at the time of classification of glacial lakes [73]. Although, numerous approaches of glacial lake classification $[6,49,55,66,68,74-77]$ are present in the scholarly literature. However, as of now there has been no internationally accepted method for the classification system of glacial lakes. In the present study classification of glacial lakes was carried out by using methodology as suggested by $[55,66,74,78]$ with certain modifications. Subsequently, glacial lakes were classified into three major types as:

1. Unconnected glacial lakes: lakes that are not connected or directly-fed by the glacier e.g., glacier erosion lakes (cirque erosion lake, glacier trough valley erosion lake and other glacier erosion lakes).

2. Supraglacial lakes: lakes that are formed on the surface of the glacier.

3. Proglacial lakes: lakes which are generally dammed by moraines and are in contact with the glacier or in the vicinity of the glacier. Here in this study lakes which are directly fed by the glaciers are also classified in this category as in case of Refs. [55, 74]. 


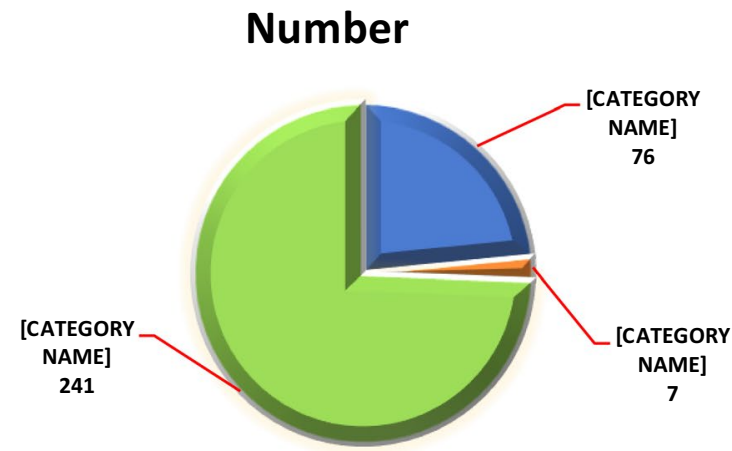

Prog lacial lakes Supra-glacial lakes Unconected glacial lakes

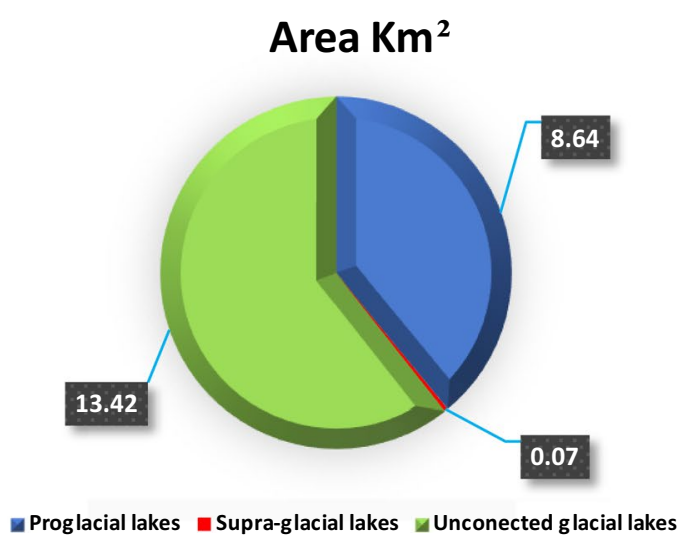

Fig. $3 \mathbf{a}$ and $\mathbf{b}$ showing number and area of glacial lake type

\subsection{The uncertainty analysis}

In the present study, glacial lakes were identified, delineated, and mapped to observe changes in spatial extent using multidate/multisensor remote sensing data. Uncertainties in glacial lake mapping occur mainly due to image coregistration, area delineation and editing using manual interpretation. As a result, thorough consideration of errors is required to determine the accuracy and relevance of the findings. High-resolution satellite imagery would be the most precise way to assess the errors related to glacial lake outlines [50]. However, high-resolution satellite data were not available for the present research work. Therefore, we used Landsat satellite data in conjunction with high-resolution Google Earth imagery to maintain the accuracy of glacial lake boundaries. The primary errors of coregistration and lake outlines that could have resulted in various levels of accuracy were considered in this study. Most of the Landsat scenes have similar resolutions. The glacial lakes are clear on almost all the scenes utilized in the study with less snow and cloud cover, and the manually delineated lake boundaries were checked two times simultaneously by a single operator.

Initially, Landsat ETM+ images were merged with Pan images with high resolution to create a high-resolution pansharpened image by employing the methodology suggested by [21,50]. All other images were coregistered with the pansharpened ETM+ image within $7.5 \mathrm{~m}$ for TM and OLI images, using it as the base map. Consequently, after the image coregistration, geometrical rectification of all images was carried out with the same projected coordinate system of WGS 1984 UTM Zone 43. The remote sensing uncertainty formula [21,32] was used to estimate the terminus change uncertainty $(U)$.

$$
U=\sqrt{a^{2}+b^{2}+\sigma}
$$

where $\mathrm{a}$ and $\mathrm{b}$ are the resolutions of the image and $\sigma$ is the co-registration error of the images to the base image in Eq. (2). We estimated a terminus accuracy of $47.3 \mathrm{~m}$ for Landsat TM and ETM+ and $49.6 \mathrm{~m}$ for OLI images.

The uncertainties related to lake area have also been estimated through Eq. (3), as suggested by Yao et al. [8].

$$
\text { Uarea }=2 \mathrm{UV}
$$

where $U$ and $V$ are the glacier area uncertainty and pixel resolution, respectively.

In this way, the area uncertainties of the glacial lakes were found to be $0.003 \mathrm{~km}^{2}(0.3 \%)$ for TM and ETM+ and $0.0025 \mathrm{~km}^{2}(0.25 \%)$ for OLI images. Thus, the overall uncertainty was estimated to be $0.005 \mathrm{~km}^{2}(0.55 \%)$, which are well or below the previously reported acceptable ranges $[21,50,79]$. 


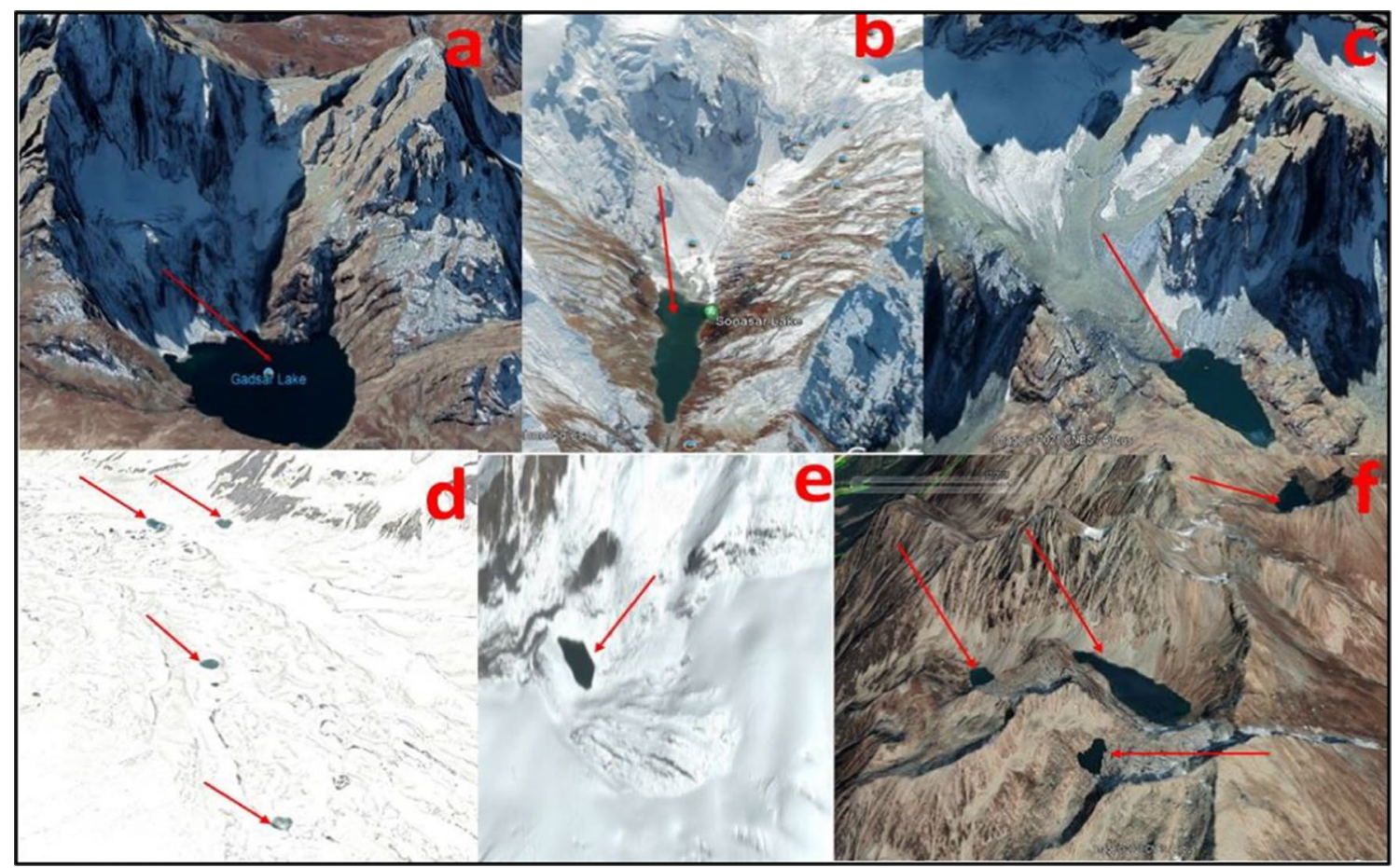

Fig. 4 Showing types of glacial lakes. a-c Proglacial Lakes. $\mathbf{d}$, e Supraglacial Lake and $\mathbf{f}$ unconnected glacial lakes

\section{Results and discussion}

\subsection{Glacial lakes in 2018}

Using Landsat (OLI) imagery from 2018 with $30 \mathrm{~m}$ spatial resolution, a total of 324 glacial lakes were identified in the UJB, with a total calculated area of approximately $22.11 \mathrm{~km}^{2}$. The area of the glacial lakes varied from 0.001 to $1.65 \mathrm{~km}^{2}$ with an average size of $0.06 \mathrm{~km}^{2}$. Glacial lakes in the region are not evenly distributed, the majority of glacial lakes are located in the Sindh and Lidder catchments of the basin, accounting for almost $68 \%$ of the total lakes. The Gangabal lake located in Sind watershed possesses the highest area of $1.67 \mathrm{~km}^{2}$, whereas lowest area was found to be $0.001 \mathrm{Km}^{2}$ for Dont-Sar Lake in Vaishav catchment.

Of the total glacial lakes mapped for the year 2018, 76 are proglacial lakes (generally moraine dammed, ice dammed lakes and other moraine dammed lakes fed by the glacier) 241 unconnected glacial lakes that are not fed by the glaciers (Cirque lakes and other erosion lakes) and 7 glacial lakes were identified as supraglacial lakes (developed on the surface of glaciers) (Fig. 3a). Unconnected glacial lakes cover the highest area $13.42 \mathrm{~km}^{2}$ which is approximately $61 \%$ of the total area of glacial lakes in the basin. Proglacial lakes and supraglacial lakes accounts $8.64 \mathrm{~km}^{2}(39 \%)$ and $0.07 \mathrm{~km}^{2}(0.3 \%)$ of the total area respectively (Fig. 3b). The representation of glacial lake types is depicted in (Fig. 4).

The majority of the glacial lakes are small in size, i.e., less than $0.1 \mathrm{~km}^{2}$ contributes 271 of the total number and $5.67 \mathrm{~km}^{2}$ of the total area, which are $83.64 \%$ and $25.64 \%$, respectively. Lakes with sizes greater than $0.1 \mathrm{~km}^{2}$ constitute only 52 in number but contribute $16.54 \mathrm{~km}^{2}$ of area, which is approximately $75 \%$ of the total surface area of the glacial lakes in the study region. Lakes with an area $>0.1 \mathrm{~km}^{2}$ are considered dangerous because they possess an enormous volume of water to cause a flash flood in the downstream region [80, 81]. Among 52 lakes greater than $0.1 \mathrm{~km}^{2} 19$ are proglacial lakes and 33 are unconnected glacial lakes. The details of the glacial lakes greater than $0.1 \mathrm{~km}^{2}$ in the study region are mentioned in Table 3 . All glacial lakes in the study area are located at an elevation range between $2700-4500 \mathrm{~m}$ asl. The majority of glacial lake area, i.e., $68 \%$, is concentrated in the elevation zone of 3650-4150 m. 


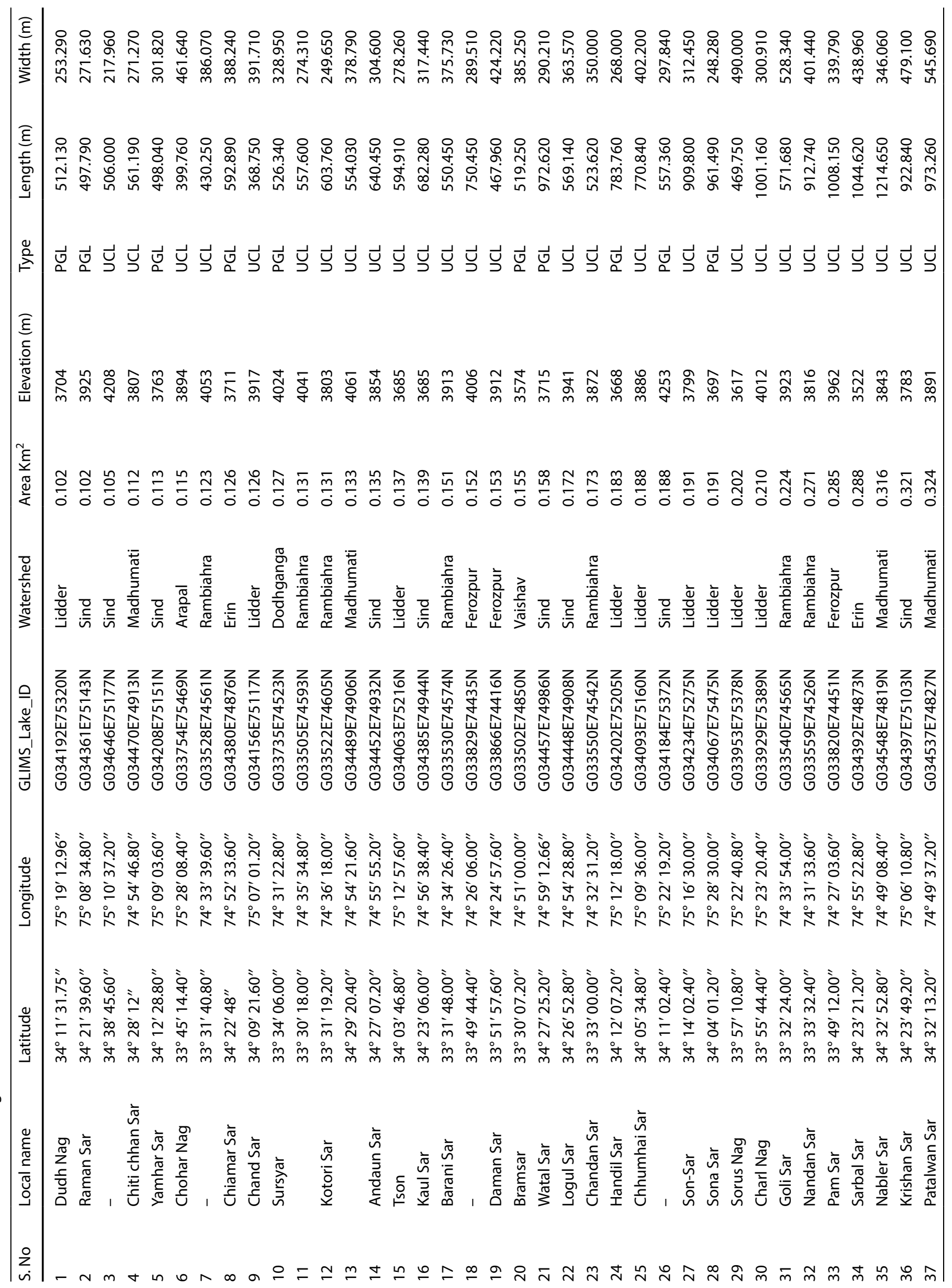




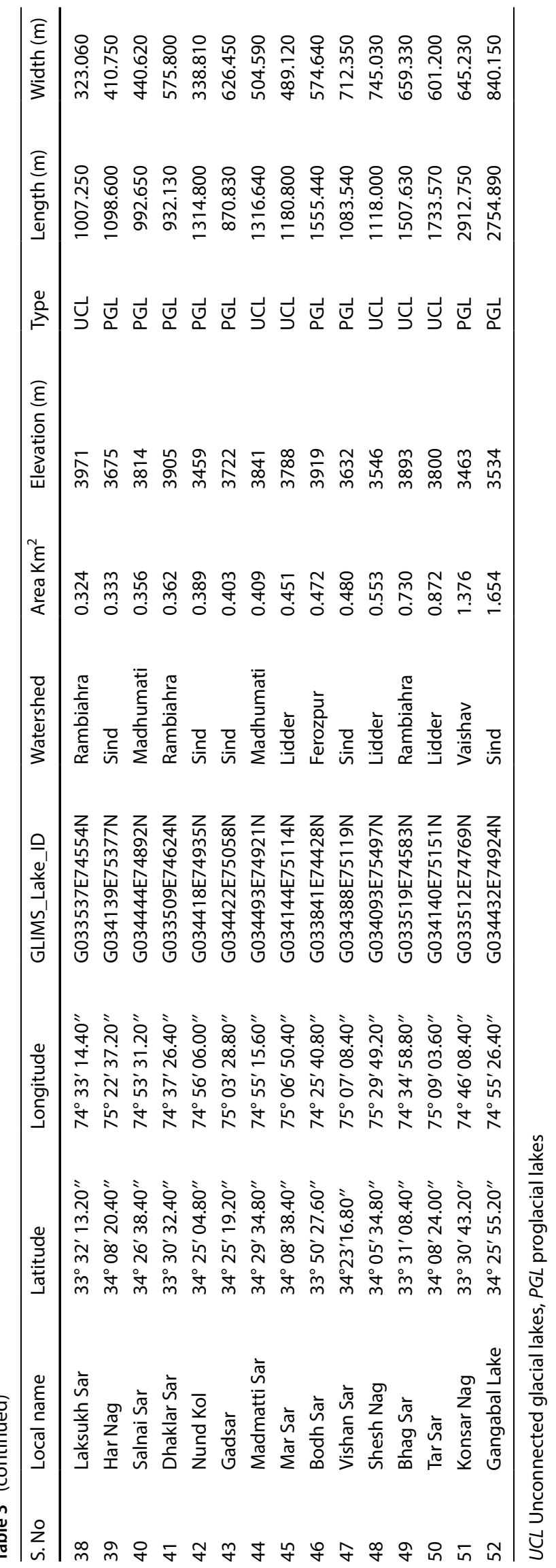


Table 4 Glacial Lake count and area in 1990, 2000, 2010 and 2018

\begin{tabular}{|c|c|c|c|c|c|c|c|c|c|c|}
\hline \multirow[t]{2}{*}{ Area range $\left(\mathrm{km}^{2}\right)$} & \multicolumn{2}{|l|}{1990} & \multicolumn{2}{|l|}{2000} & \multicolumn{2}{|l|}{2010} & \multicolumn{2}{|l|}{2018} & \multicolumn{2}{|c|}{$\begin{array}{l}\text { 1990-2018 } \\
\text { Change }\end{array}$} \\
\hline & Count & $\mathrm{Km}^{2}$ & Count & $\mathrm{Km}^{2}$ & Count & $\mathrm{Km}^{2}$ & Count & $\mathrm{Km}^{2}$ & Count & $\mathrm{Km}^{2}$ \\
\hline$\leq 0.01$ & 103 & 0.49 & 112 & 0.57 & 110 & 0.60 & 121 & 0.59 & 18 & 0.10 \\
\hline $0.01-0.05$ & 77 & 1.70 & 82 & 1.92 & 124 & 2.94 & 115 & 2.68 & 38 & 0.98 \\
\hline $0.05-0.10$ & 25 & 1.72 & 25 & 1.84 & 27 & 2.01 & 34 & 2.42 & 09 & 0.70 \\
\hline $0.10-1.0$ & 46 & 12.20 & 46 & 12.23 & 47 & 12.52 & 50 & 13.42 & 04 & 1.22 \\
\hline$>1.0$ & 02 & 2.73 & 02 & 2.75 & 02 & 2.96 & 02 & 3.00 & 0 & 0.27 \\
\hline Total & 253 & 18.84 & 267 & 19.31 & 310 & 21.03 & 324 & 22.11 & 71 & 3.27 \\
\hline
\end{tabular}
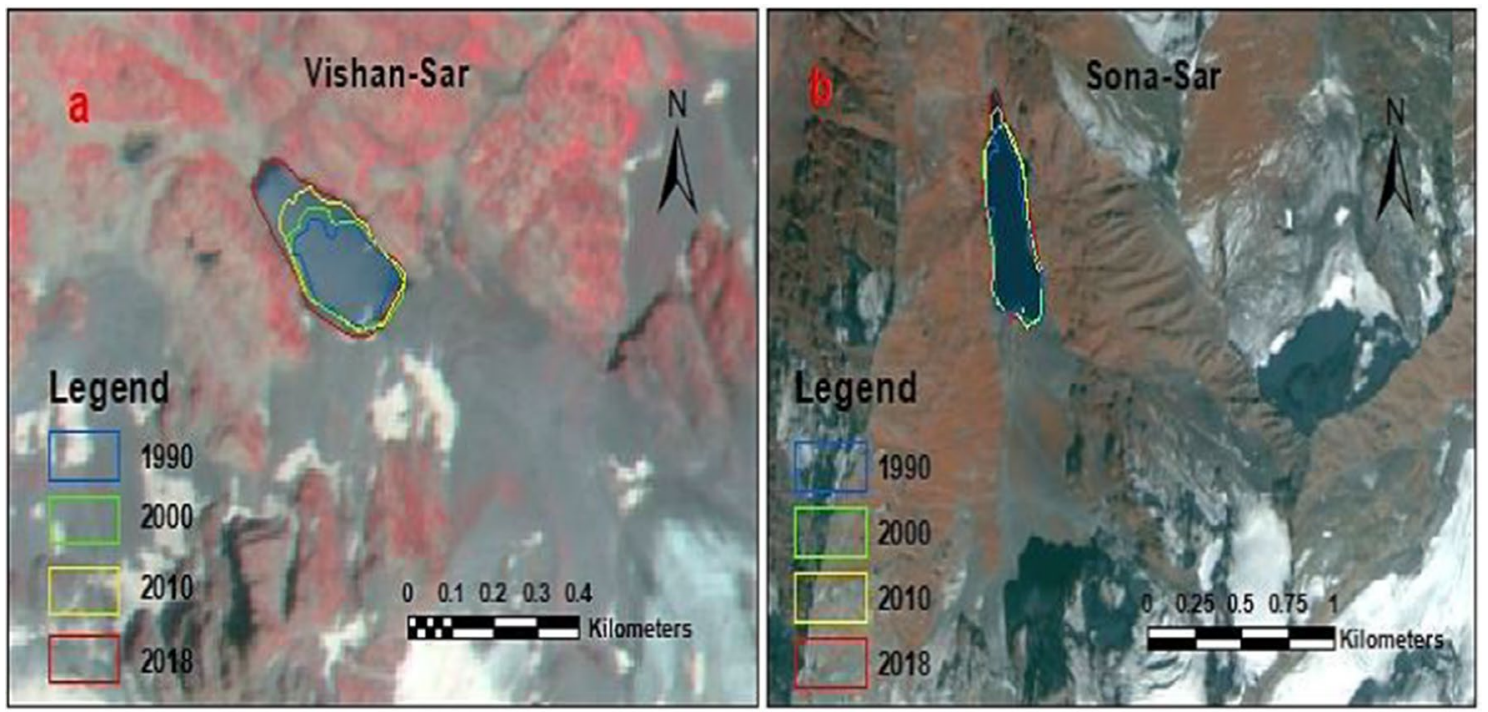

Fig.5 a, b show area changes in two major glacial lakes within the study area

Table 5 Newly formed glacial lakes and extinct lakes from 1990 to 2018

\begin{tabular}{|c|c|c|c|c|c|c|c|c|c|}
\hline \multirow[t]{2}{*}{ Year } & \multirow[t]{2}{*}{ Total number } & \multirow{2}{*}{$\begin{array}{l}\text { Total } \\
\text { change } \\
\text { area }\left(\mathrm{km}^{2}\right)\end{array}$} & \multicolumn{2}{|c|}{ Newly formed } & \multicolumn{2}{|c|}{ Disappeared } & \multicolumn{3}{|l|}{ Existing } \\
\hline & & & Number & $\mathrm{km}^{2}$ & Number & $\mathrm{km}^{2}$ & Number & $\begin{array}{l}\text { Change } \\
\mathrm{km}^{2}\end{array}$ & $\begin{array}{l}\text { Contribution of } \\
\text { the area change } \\
\text { (\%) }\end{array}$ \\
\hline 1990 & 253 & - & - & - & - & - & - & - & - \\
\hline 2000 & 267 & +0.47 & 10 & 0.15 & 4 & 0.08 & 253 & 0.40 & 85.10 \\
\hline 2010 & 310 & +1.72 & 36 & 0.47 & 7 & 0.10 & 260 & 1.36 & 79.06 \\
\hline 2018 & 324 & +1.09 & 11 & 0.13 & 3 & 0.06 & 307 & 1.01 & 93.51 \\
\hline
\end{tabular}

\subsection{Glacial lake expansion (1990-2018)}

The glacial lakes in the Kashmir Himalayas evolved and increased in number and size over time, particularly from 1990 to 2018 , with $253\left(18.84 \pm 0.02 \mathrm{~km}^{2}\right), 267(19.31 \pm 0.02), 310(21.03 \pm 0.02)$, and $324\left(22.13 \pm 0.002 \mathrm{~km}^{2}\right)$ glacial lakes identified and mapped in 1990, 2000, 2010, and 2018, respectively. The total lake area has increased by $3.28 \pm 0.013$ $\mathrm{km}^{2}(14.8 \%)$ in last three decades. The total area has increased by $0.10 \mathrm{~km}^{2} \pm 0.013$ for glacial lakes with size $\leq 0.01$, $1.22 \mathrm{~km}^{2} \pm 0.013$ with size $>0.10 \mathrm{~km}^{2}$ and $\leq 1.0 \mathrm{~km}^{2}$ and $0.27 \pm 0.013 \mathrm{~km}^{2}$ with size $>1.0 \mathrm{~km}^{2}$ from 1900-2018 (Table 4, Fig. 5). Hence, the small glacial lakes have contributed less to the total area change, i.e., expanded more slowly than 
Table 6 Total increase in the area of major glacial lake types from 1990-2018

\begin{tabular}{|c|c|c|c|c|c|c|}
\hline \multirow[t]{2}{*}{ Type } & \multicolumn{2}{|c|}{ Number } & \multicolumn{2}{|c|}{ Area $\mathrm{Km}^{2}$} & \multicolumn{2}{|c|}{ Change (1990-2018) } \\
\hline & 1990 & 2018 & 1990 & 2018 & Number & Area $\mathrm{Km}^{2}$ \\
\hline Proglacial lakes & 57 & 76 & 6.36 & 9.04 & 19 & 2.68 \\
\hline Supra-glacial lakes & 1 & 7 & 0.003 & 0.07 & 6 & 0.067 \\
\hline Unconnected glacial lakes & 195 & 241 & 12.49 & 13.02 & 46 & 0.53 \\
\hline Total & 253 & 324 & 18.85 & 22.13 & 71 & 3.28 \\
\hline
\end{tabular}
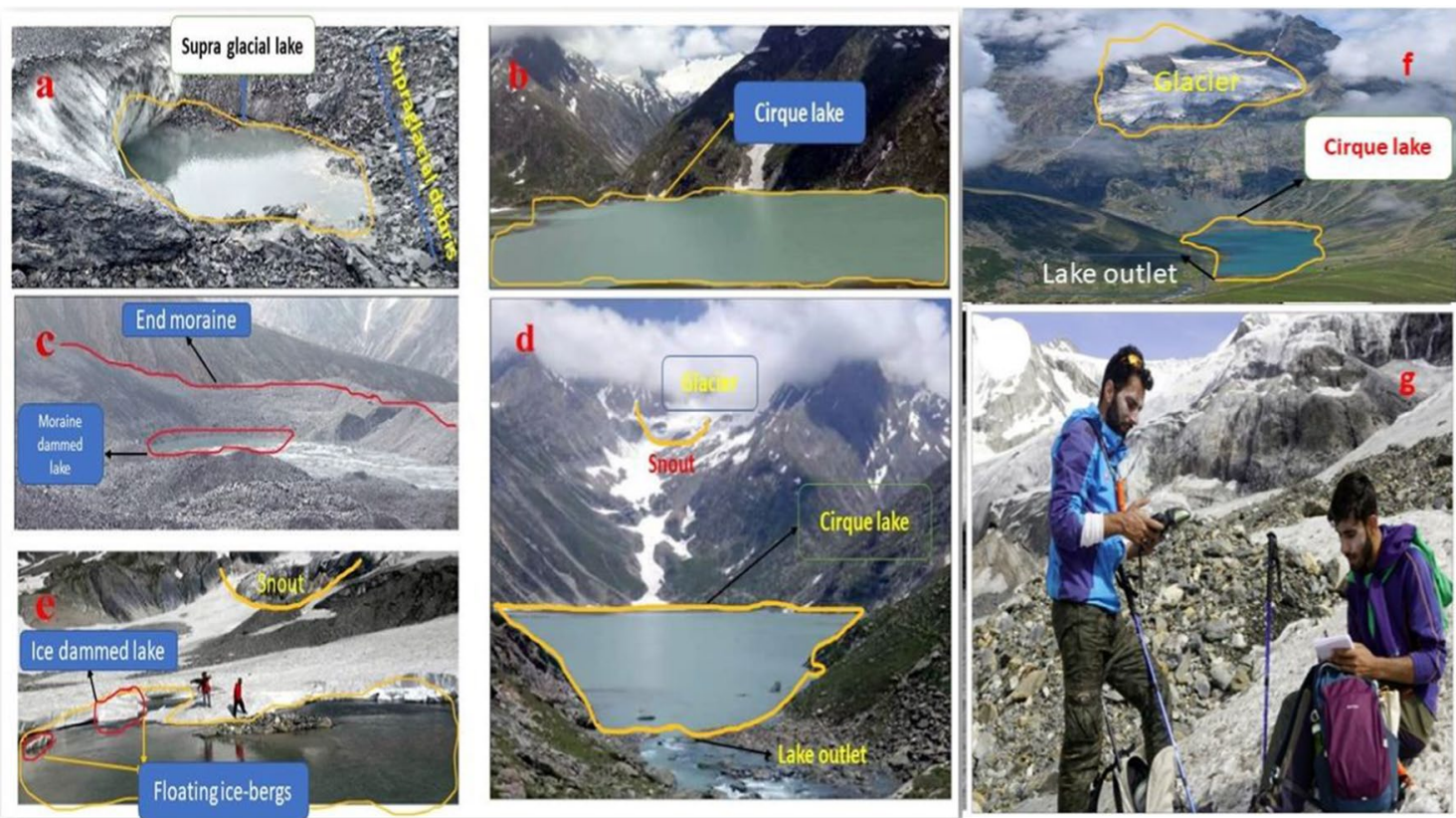

Fig. 6 Photographs taken during the flied visit of the study area showing various types of glacial lakes: a supra-glacial lakes, $\mathbf{b}$, $\mathbf{d}$ and $\mathbf{f}$ cirque lakes, $\mathbf{c}$ and $\mathbf{e}$ moraine and ice dammed glacial lakes and $\mathbf{g}$ on field DGPS observations

the large ones, similar to what [6] reported in the Central Himalayan region. The smaller lakes are so dynamic that they appear and disappear over time (Table 4, Fig. 5), as confirmed by [53].

More than $78 \%$ of existing glacial lakes show an obvious increase in the spatial extent over the 28-year study period. The processes of glacial lake area change were intricate, consisting of expansion in areas of larger glacial lakes as well as the appearance and disappearance of small glacial lakes. Newly developed glacial lakes were found three times more in number than glacial lakes that were extinct, i.e., $57>14$ over time.

The newly formed glacial lakes, therefore, have a small contribution to lake expansion in the Kashmir Himalaya. (Table 5), similar to the Central Himalayas reported by [6].

The study reveals that the proglacial lakes showed greater expansion in comparison to supraglacial and unconnected glacial lakes, the latter being dynamic in nature. Proglacial lakes increased lesser in number i.e., 19 as compared to the unconnected glacial lakes which have increased from $195\left(12.49 \mathrm{~km}^{2}\right)$ in 1990 to $241\left(13.02 \mathrm{~km}^{2}\right)$ in 2018 . The unconnected glacial lakes show lower expansion rates, i.e., $0.53 \mathrm{~km} 2(16.2 \%)$ of an overall increase in lake area. On the other hand, proglacial lakes have shown highest expansion rate of $2.68 \mathrm{~km}^{2}(82 \%)$ over the period of 28 years. Supraglacial lakes are very less in the study area accounts 7 of the total number and $0.067 \mathrm{~km}^{2}$ of the total area. The area of supraglacial lakes has increased from $0.003 \mathrm{~km}^{2}$ to $0.07 \mathrm{~km}^{2}$ from 1990 to 2018 , thus showing an overall increase of $0.067 \mathrm{~km}^{2}$ which is $2 \%$ of the total growth of area (Table 6 ).

\subsubsection{Altitudinal differences}

Altitude is an important controlling factor for the change in surface area of glacial lakes [58, 82]. All the identified glacial lakes in the study region were normally distributed between 2700 and $4500 \mathrm{~m}$ asl. The majority of them were 
concentrated in the elevation range of $3800 \mathrm{~m}$ asl to $4300 \mathrm{~m}$ asl. This is largely due to an enabling environment and peculiar geomorphological setting for glacier lake development in the study region. Hence, maximum glacial lake changes ( $\geq 91 \%$ ) occurred at elevations between 3800 and $4300 \mathrm{~m}$ asl from 1990 to 2018 . The area of glacial lakes has also shown variation in terms of different altitudinal ranges. Glacial lakes below $2900 \mathrm{~m}$ asl and above $4500 \mathrm{~m}$ asl share a minimum number and area of lakes, whereas the majority of the glacial lake area, i.e., $68 \%$, is concentrated between the elevation zones of 3650-4150 $\mathrm{m}$ asl.

\subsubsection{Field investigations}

Field measurements of high-altitude lakes are difficult to accurately ascertain in steeply edged mountainous remote areas [68]. Field study experiences, however, still confirm the location, shape and size of such lakes. To supplement our study, we conducted a five (05) day field visit to glacial lakes in the study area from 7-11 October 2019.

During our visit, we could only identify a sizable number of glacial lakes due to inaccessibility issues and hostile conditions in the study region. We identified lakes broadly classified as supra glacial, cirque, moraine and ice dammed glacial lakes (Fig. 6a-f) and crosschecked them with the first glacial lake inventory prepared from Landsat images for 2018 to make corrections in lake outlines and obtain the final glacial lake inventory for 2018. Furthermore, various glacial lake parameters, such as latitude, longitude, and elevation, were taken using a differential global positioning system (DGPS). A laser distance meter (LDM) was used to calculate the length and width of the lakes. Various geomorphological parameters of lakes identified during the field investigation are presented in Fig. 6a-f. The main purpose of the field investigation of selected lakes was to validate the inventoried glacial lakes on the ground. The coordinates taken during the field visit of selected lakes showed a minor error in terms of location. The elevation on the ground and elevation derived from the DEM also showed a minor error of approximately 4-10 m. For example, Gangabal Lake, which is located in the Sind catchment, has an elevation of $3534 \mathrm{~m}$ derived from the DEM, whereas DGPS on the ground has shown an elevation of $3537 \mathrm{~m}$. Similarly, Sheshnag in the Lidder catchment has a DEM-generated elevation of $3564 \mathrm{~m}$, whereas it has shown $3573 \mathrm{~m}$ on the ground.

\subsection{Possible causes of glacial lake changes}

The meltwater of glaciers makes a significant contribution to glacial lake growth in the Himalayan region [6], in which proglacial lakes show an obvious increase in expansion with increasing meltwater $[13,68,83,84]$. Ice or glacial melt water drives the expansion of proglacial lakes in the region. The climatic variables (e.g., temperature and precipitation) of the Kashmir valley show substantial changes from 1980-2014 [85], with an increase in mean maximum and minimum temperatures and annual precipitation showing a downward trend from 1980 to 2018 [72]. The observed extreme warm temperatures in the past have resulted in the remarkable retreat of glaciers in the Western Himalayas [60, 86-88]. Understanding that assessing climate change impact on glacial lakes is a tedious process and cannot singly be a reason for glacial lake expansion [68], the melting of glaciers in the Central Himalayas is exacerbated by the presence of increased light trapping particles (such as black carbon and dust) that may also contribute to the development of glacial lakes [89].

Our study used historical observed meteorological data from the Pahalgam weather station (2310 masl) for 1980 to 2020 obtained from the Indian Meteorological Department, Meteorological Centre Srinagar to analyse the temperature and precipitation trends in the study region. The analysis of climatic data revealed that the minimum and maximum temperatures have shown an increasing trend, whereas precipitation has shown a decreasing trend by using non-parametric Mann-Kendall test and Thel-Sen method at $95 \%$ of confidence level. $\mathrm{T}_{\max }$ showed an increase of $1.25^{\circ} \mathrm{C}$, whereas $\mathrm{T}_{\min }$ increased to $0.7^{\circ} \mathrm{C}$ from 1980 to 2020 (Fig. $7 \mathrm{a}$ ). $\mathrm{T}_{\max }$ is increasing at the rate of $0.03^{\circ} \mathrm{C} /$ year and $\mathrm{T}_{\min }$ at $0.017^{\circ} \mathrm{C} /$ year. On the other hand, precipitation has shown a decreasing trend $-1.69^{\circ} \mathrm{C} /$ year (Fig. $7 \mathrm{~b}$ ), which can account for a major cause of glacier recession and subsequent lake expansion in the study region. Although there could be various underlying causes for such changes, climatic variability appears to be a possible cause for glacial lake changes in the study region.

\section{Discussions}

The Himalayan cryosphere acts as a major source of water for downstream regions and has important interconnections with ecosystems and socioeconomic benefits $[9,30]$. Glaciers and glacial lakes in the Jhelum Basin of the Kashmir Himalayas are vital sources to headwaters of the Indus River basin and supports hydropower generation, irrigation, domestic 
$\longrightarrow$-T_Max - - T_Min - T_Avg.

(a)
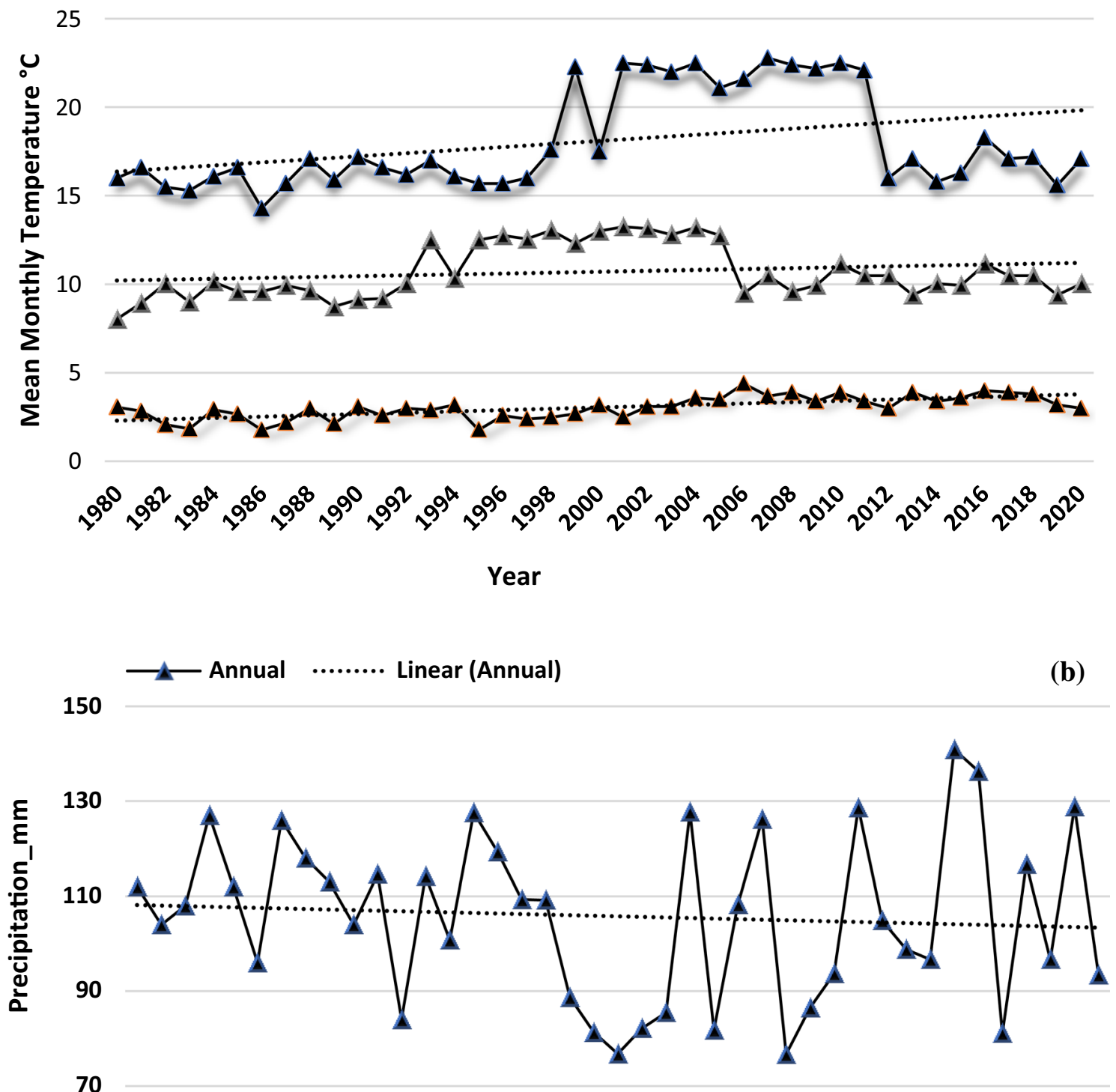

50

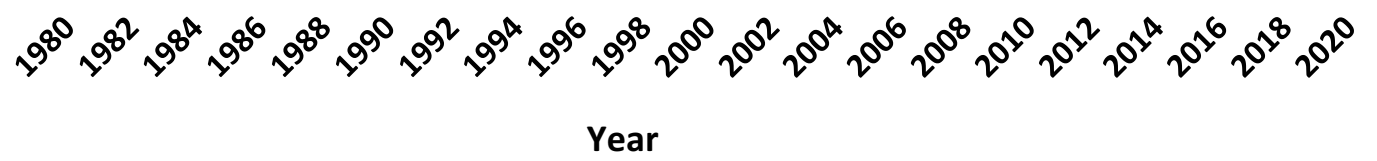

Fig.7 Trends in the essential climatic variables in the study area (1990-2018). a Annual minimum, maximum, average temperature. b Annual precipitation

uses and tourism in the downstream areas [57]. With increasing temperatures in the Himalayan region under the global climate change, glaciers are melting at an enhanced rate, leading to the formation and expansion of various types of glacial lakes.

The total count of glacial lakes mapped in the study region as well as their spatial extent showed a discernible increase. The number has increased from 253 in 1990 to 324 in 2018, with a growth rate of 21.4\%. The area has increased from $18.84 \mathrm{~km}^{2}$ in 1990 to $22.13 \mathrm{~km}^{2}$ in 2018 with a growth rate of $14.7 \%$. The newly formed glacial lakes, including supra glacial lakes, were greater in number than the lakes that have disappeared over time. Lake expansion is not limited to 
the North-Western Himalayas, the phenomenon has also been witnessed in other parts of the Himalayan region and has been well documented in the scholarly literature, for example Central Himalayas have shown an expansion rate of $24 \%$ [90], Nepal 25\% [19], Namco basin 16.7\% [91], Koshi basin 31.5\% [53], Entire Third Pole 23\% [28], Chandra basin 41.41\% [92] and Nepal and Bhutan 20-60\% [68].

The classification of glacial lakes becomes problematic when there are several studies that classify/categorize lakes differently based on certain characteristics and no common consensus is developed to standardise a selection criterion and overcome such a problem. In the present study, we classified glacial lakes as (1) Unconnected lakes; (2) Proglacial lakes; and (3) Supra-glacial lakes after the methodology adopted by major studies such as $[55,66,74,78]$.

The analysis of climatic variables (temperature and precipitation) reveals that the minimum and maximum temperatures in the study region show an increasing trend, while as precipitation is showing a decreasing trend, as well as reported by $[72,85]$. A persistent warming trend that has developed over the western Himalayas is seen as a major cause of glacier recession in the region $[60,85,86]$. The shrinking and thinning of glaciers may result in further expansion of glacial lakes, hence increasing the possibility of potentially dangerous glacial lakes in the region.

Glacier melt water is apparently a major contributor for glacial lake expansion in the study region. Nevertheless, the impact of climate change on glacial lakes is too complex a process to understand owing to certain limitations in terms of hydro-metrological data networks and glacier observation sites in the region, it is therefore a matter of future investigation whether climate change is singly responsible for glacial lake change in the study region.

\section{Conclusions}

The selected study sites in the Kashmir Himalayas have a complex and rugged topography in addition to the limited network of observational sites (e.g., meteorological and glaciological). This proves to be a major obstacle in conducting extensive field investigations and understanding the occurrences of dynamic environmental processes in the region.

This study systematically observes the spatiotemporal changes in glacial lakes across the Kashmir Himalaya from 1990-2018 using Landsat images supplemented by ground observations. The Landsat images with 30 m resolution used for four time points $(1990,2000,2010$, and 2018) make this entire process of glacial lake change detection more reliable by reducing any uncertainties.

This analysis further revealed that the overall glacial lakes pertaining to the present study showed a substantial increase in count and area through 1990-2018. Area has increased from $18.84 \mathrm{~km}^{2}$ in 1990 to $22.13 \mathrm{~km}^{2}$ in 2018 with a growth rate of $14.7 \%$. The number increased from 253 in 1990 to 324 in 2018, with a growth rate of $21.4 \%$. The already existing lakes have contributed more to area expansion than newly developed glacial lakes, with maximum changes occurring in the elevation range of $3800 \mathrm{~m}$ asl and 4300 masl.

Glacial lakes that are expanding at higher rates should be taken as case studies for potential GLOF events in the future. Consequently, continuous monitoring and observation specifically focused on area change, lake volumes and outburst scenarios/simulation studies. Furthermore, the development of integrated socio technology-driven early warning systems (EWSs) and the generation of public awareness may help us to reduce the risk of GLOF hazards in the region. The supplementary data related to this research article is freely available at https://doi.org/10.5281/zenodo.5016511.

Acknowledgements The authors are thankful to the United States Geological Survey (USGS) for freely providing the satellite data used in this study. The first author acknowledges the support of the University Grants Commission (UGC) in the form of grants made available under the MANF-JRF scheme for pursuing Ph.D. The corresponding author acknowledges the support of MOES \& NCPOR under HiCom Initititaive.

Authors' contributions Every author has contributed to the successful compilation of this study. RA, GFW, and STA: Conceptualization, Methodology, Software, Writing - original draft, Formal analysis. RAM and MA: Data curation, Formal analysis, Writing一review \& editing. SKJ and PA: Writing-review, editing, Supervision. All authors read and approved the final manuscript.

Funding No funding was received to carry out this study.

Data availability All data generated or analysed during this study are included in this published article.

Declarations

Ethical approval All the ethical standards of research publishing were taken care of during this study.

Competing interests The authors declare no competing interests. 
Open Access This article is licensed under a Creative Commons Attribution 4.0 International License, which permits use, sharing, adaptation, distribution and reproduction in any medium or format, as long as you give appropriate credit to the original author(s) and the source, provide a link to the Creative Commons licence, and indicate if changes were made. The images or other third party material in this article are included in the article's Creative Commons licence, unless indicated otherwise in a credit line to the material. If material is not included in the article's Creative Commons licence and your intended use is not permitted by statutory regulation or exceeds the permitted use, you will need to obtain permission directly from the copyright holder. To view a copy of this licence, visit http://creativecommons.org/licenses/by/4.0/.

\section{References}

1. Fitzsimons S, Howarth J. Glaciolacustrine. In: Menzies J, Van der Meer JM. Past glacial environments, 2nd edn. Elsevier; 2018. p. 309-34. https://doi.org/10.1016/B978-0-08-100524-8.00009-9.

2. Campbell JG, Pradesh H. Inventory of glaciers and glacial lake and the identification of potential glacial lake outburst floods (GLOFs) affected by global warming in the mountains of India, Pakistan and China/Tibet Autonomous Region. International Centre for Integrated Mountain Development (ICIMOD), GP O. Box, 3226; 2005.

3. Benn D, Lehmkuhl F. Mass balance and equilibrium-line altitudes of glaciers in high-mountain environments. Quatern Int. 2000;65:15-29. https://doi.org/10.1016/S1040-6182(99)00034-8.

4. Richardson S, Reynolds J. An overview of glacial hazards in the Himalayas. Quatern Int. 2000;65:31-47.

5. Bajracharya S, Mool P. Growth of hazardous glacial lakes in Nepal. In: Proceedings of the JICA regional seminar on natural disaster mitigation and issues on technology transfer in south and southeast Asia, 30; 2005, p. 131-48.

6. Nie Y, Liu Q, Liu S. Glacial lake expansion in the central Himalayas by landsat images, 1990-2010. PLoS ONE. 2013;8(12):e83973.

7. Worni R, Stoffel M, Huggel C, Volz C, Casteller A, Luckman B. Analysis and dynamic modeling of a moraine failure and glacial lake outburst flood at Ventisquero Negro, Patagonian Andes (Argentina). J Hydrol. 2012;444:134-45.

8. Yao T, Li Z, Yang W, Guo X, Zhu L, Kang S, et al. Glacial distribution and mass balance in the Yarlung Zangbo River and its influence on Lakes. Chin Sci Bull. 2010;55(20):2072-8.

9. Ahmed R, Ahmad ST, Wani GF, Ahmed P, Mir AA, Singh A. Analysis of landuse and landcover changes in Kashmir valley, India-a review. GeoJournal. 2021. https://doi.org/10.1007/s10708-021-10465-8.

10. Bahuguna IM, Rathore BP, Brahmbhatt R, Sharma M, Dhar S, Randhawa S, et al. Are the Himalayan glaciers retreating? Curr Sci. 2014;106(7):1008-13.

11. Bajracharya SR, Mool PK, Shrestha BR. The impact of global warming on the glaciers of the Himalaya. In: Proceedings of the international symposium on geodisasters, infrastructure management and protection of world heritage sites; 2006. p. 231-42.

12. Bajracharya SR, Mool PK, Shrestha BR. Impact of climate change on Himalayan glaciers and glacial lakes: case studies on GLOF and associated hazards in Nepal and Bhutan. Kathmandu: International Centre for Integrated Mountain Development (ICIMOD); 2007.

13. Bolch T, Pieczonka T, Benn DI. Multi-decadal mass loss of glaciers in the Everst area (Nepal Himalaya) derived from stereo imagery. Cryosphere. 2011;5(2):349-58.

14. Muhammad S, Tian L, Nusser M. No significantmass loss in the glaciers of Astore Basin (North-Western Himalaya), between 1999 and 2016. J Glaciol. 2019;65(250):270-8.

15. Zhou Y, Li Z, Li J. Slight glacier mass loss in the Karakoram region during the 1970 s to 2000 revealed by KH-9 images and SRTM DEM. J Glaciol. 2017;63(238):331-42.

16. Bajracharya SR. Impacts of climate change on Himalayan glaciers and glacial lakes: case studies on GLOF and associated hazards in Nepal and Bhutan. Kathmandu: International Centre for Integrated Mountain Development (ICIMOD); 2007.

17. Berthier E, Arnaud Y, Kumar R, Ahmed S, Wagnon P, Chevallier P. Remote sensing estimates of glacier mass balances in the Himachal Pradesh ( western Himalaya, India). Remote Sens Environ. 2007;108(3):327-38.

18. Bhambri R, Misra A, Kumar A, Gupta A, Verma A, Tiwari S. Glacier lake inventory of Himachal Pradesh. Himalayan Geol. 2018;39:1-33.

19. Khadka N, Zhang G, Thakuri S. Glacial lakes in the Nepal Himalaya: inventory and decadal dynamics (1977-2017). Remote Sens. 2018;10(12):1913.

20. Kulkarni AV, Rathore BP, Singh SK, Bahuguna IM. Understanding chnages in the Himalayan cryosphere using remote sensing techniques. Int J Remote Sens. 2011;32(3):601-15.

21. Mir RA, Jain SK, Jain SK, Thayyen RJ, Saraf AK. Assessment of recent glacier changes and its controlling factors from 1976 to 2011 in Baspa basin, western Himalaya. Arct Antarct Alp Res. 2017;49(4):621-47.

22. Romshoo SA, Dar RA, Rashid I, Marazi A, Ali N, Zaz SN. Implications of shrinking cryosphere under changing climate on the streamflows in the Lidder catchment in the Upper Indus Basin, India. Arct Antarct Alp Res. 2015;47(7):627-44.

23. Wagnon P, Linda A, Arnaud Y, Kumar R, Sharma P, Vincent C, et al. Four years of mass balance on Chhota Shigri Glacier, Himachal Pradesh, India, a new benchmark glacier in the western Himalaya. J Glaciol. 2017;53(183):603-11.

24. Ahmad ST, Ahmed R, Wani GF, Sharma P, Ahmed P. Glacier changes in Sind basin (1990-2018) of North-western Himalayas using earth observation data. Model Earth Syst Environ. 2021. https://doi.org/10.1007/s40808-021-01246-w.

25. Agarwal A, Tayal S. Assessment of volume changes in East Rathong glacier, Eastern Himalaya. Int J Geoinform. $2013 ; 9(1): 73-82$.

26. Valenzuela SM, Mckinney DC, Rounce DR, Byers AC. Changes in Imja Tsho in the Mount Everest region of Nepal. Cryosphere. 2014;8(5):1661-71.

27. Watanabe T, Lamsal D, Ives JD. Evaluating the growth charecteristics of glacial a glacial lake and its degree of danger of outburst flooding: Imja Glacier, Khumbu Himal, Nepal. Norwegian J Geogr. 2009;63(4):255-67.

28. Zhang G, Yao T, Xie H, Wang W, Yang W. An inventory of glacial lakes in the Third Pole region and their chnages in response to global warming. Glob Planet Change. 2015;131:148-57. 
29. Raj K, Kumar KV. Inventory of glacial lakes and its evolution in Uttarakhand Himalaya using time series sattelite data. J Indian Soc Remote Sens. 2016;44(6):959-76.

30. Ives JD, Shrestha RB, Mool PK. Formation of glacial lakes in the hindu Kush-Himalayas and GLOF risk assessment. Kathmandu: International Centre for Integrated Mountain Development (ICIMOD); 2010.

31. Quincey DJ, Lucas RM, Richardson SD, Glasser NF, Hambrey MJ, Reynolds JM. Optical remote sensing techniques in high-mountain environments: application to glacial hazards. Progr Phys Geogr. 2005;29(4):475-505.

32. Yao T, Thompson L, Yang W, Yu W, Gao Y, Guo X, Joswiak D. Different glacier status with atmospheric circulations in Tibetan Plateau and surroundings. Nat Clim Chang. 2012;2(9):663-7.

33. Majeed U, Rashid I, Sattar A, Allen S, Stoffel M, Nusser M, Schmidt S. Recession of Gaya Glacier and the 2014 glacial lake outburst flood in the Trans-Himalayan region of Ladakh, India. Sci Total Environ. 2020;756:144007-9.

34. Allen SK, Rastner P, Arora M, Huggel C, Stoffel M. Lake Outburst and debris flow disaster at Kedarnath, June 2013: hydro meteorological triggering and topographic predisposition. Landslides. 2016;13(6):1479-91.

35. Carrvick JL, Tweed FS. A global assessment of the societal impacts of glacier outburst floods. Glob Planet Change. 2016;144:1-16.

36. Gunn JP. The Shyok flood, 1929. Himal J. 1930;2:35-47.

37. Ives JD. Glacial lake outburst floods and risk engineering in the Himalaya: a review of the Langmoche disaster, Khumbu Himal, 4 Aug. 1985. ICIMOD occasional paper/International Centre for Integrated Mountain Development; no.10; 1986.

38. Watanbe T, Rothacher D. The 1994 LuggeTsho glacial lake outburst flood, Bhutan Himalaya. Mt Res Dev. 1996;16(1):77-81.

39. Yamada T, Sharma C. Glacier lakes and outburst floods in the Nepal Himalaya. IAHS Publ Publ Int Assoc Hydrol Sci. 1993;218:319-30.

40. Higaki D, Sato G. Erosion and sedimentation caused by glacial lake outburst floods in the Nepal and Bhutan Himalayas. Glob Environ Res. 2012;16(1):71-6.

41. Richardson SD, Quincey DJ. Glacier outburst floods from Ghulkin Glacier, Upper Hunza Valley, Pakistan. EGUGA; 2009.12871.

42. Khanal NR, Mool PK, Shrestha AB, Rasul G, Ghimire PK, Shrestha RB, Joshi SP. A comprenhensive approach and methods for glacial lake outburst flood risk assessment, with example from Nepal and the transboundary area. Int J Water Resour Dev. 2015;31(12):219-37.

43. Xu D. Characteristics of debris flow caused by outburst of glacial lake in Boqu river, Xizang, China, 1981. GeoJournal. 1988;17(4):569-80.

44. Vuichard D, Zimmermann M. The 1985 catastrophic drainage of moraine-dammed lake, Khumbu Himal, Nepal: cause and consequences. Mt Res Dev. 1987;7(2):91-110.

45. Motegi M. GLOF sediments and geology of river terraces in WangdiPhodrang district, Bhutan. J Geogr (ChigakuZasshi). 2001;110(1):17-31.

46. Huggel C, Kaab A, Haeberli W, Teysseire P, Paul F. Remote sensing based assessment of hazrad from glacier outbursts: a case study in Swiss Alps. Can Geotech J. 2002;39(2):316-30.

47. Quincey DJ, Richardson SD, Luckman A, Lucas RM, Reynolds JM, Hambrey MJ, Glasser NF. Early recognition of glacial lake hazards in Himalaya using remote sensing datasets. Glob Planet Change. 2007;56(1-2):137-52.

48. Frey H, Huggel C, Paul F, Haeberli W. Automated detection of glacial lakes based on remote sensing in view of assessing associated hazard potential. Grazer Schriften der Geography und Raumforschung. 2010;45:261-72.

49. Wang W, Xiang Y, Gao Y, Lu A, Yao T. Rapid expansion of glacial lakes caused by climate and glacier retreat in central Himalayas. Hydrol Process. 2015;29(6):859-74.

50. Mir RA, Majeed Z. Frontal recession of Parkachik Glacier between 1971-2015, Zanskar Himalaya using remote sensing and field data. Geocarto Int. 2018;33(2):163-77.

51. Mool P, Wangda D, Bajracharya S, Kunzang KA, Gurung DR, Joshi SP. Inventory of glaciers, glacial lakes and glacial lake outburst floods: monitoring and early warning system in the Hindu Kush-Himalayan Region-Bhutan. Kathmandu: International Centre for Integrated Mountain Development (ICIMOD); 2001.

52. Zhang G, Yao T, Piao S, Bolch T, Xie H, Chen D, et al. Extensive and drastically different alpine lake changes on Asia's high plateaus during the past four decades. Geophys Res Lett. 2017;44(1):252-60.

53. Shrestha F, Gao X, Khanal NR, Mahrajan SB, Shrestha RB, Wu LZ, et al. Decadal glacial lake changes in the Koshi basin, Central Himalaya, from 1977 to 2010, derived from Landsat Images. J Mt Sci. 2017;14(10):1969-84.

54. Rao BS, Gupta A, Guru N, Maheshwari SR, Raju PV, Rao VV. Glacial lake atlas of indus river Basin. National Remote Sensing Centre, ISRO: Hyderabad; 2020. p. 1-273.

55. Chen F, Zhang M, Guo H, Allen S, Kargel JS, Haritashya UK, Watson CS. Annual 30 m dataset for glacial lakes in High Mountain Asia from 2008 to 2017. Earth Syst Sci Data. 2021;13(2):741-66.

56. Hussain M. Geography of Jammu and Kashmir. New Delhi: Rajesh Publications; 2002.

57. Dar RA, Romshoo SA, Chandra R, Ahmed I. Tectono-geomorphic study of the Karewa Basin of Kashmir Valley. J Asian Earth Sci. 2014;92:143-56.

58. Ahmed R, Wani GF, Ahmad ST, Sahana M, Singh H, Ahmed P. A Review of glacial lake expansion and associated glacial lake outburst floods in the Himalayan Region. Earth Syst Environ. 2021. https://doi.org/10.1007/s41748-021-00230-9.

59. Bagnolus F. Bioclimatic types of South-East Asia. White Town: Institute Francais de Pondicherry; 1959.

60. Bhutiyani MR, Kale VS, Pawar NJ. Climate change and the precipitation variations in the northwestern Himalaya: 1886-2006. Int Climatol J R Meteorol Soc. 2010;30(4):355-548.

61. Pant RK, Agrawal DP, Krishnamurthy RV. Scannin g electron microscope and other studies on the Karewa Beds of Kashmir India: scanning electron microscopy in the study sediments Norwich. Geo Abstracts; 1978 . p. 257-82.

62. Bhardwaj A, Singh MK, Joshi PK, Singh S, Sam L, Gupta RD, Kumar R. A lake detection algorithm (LDA) using Landsat 8 data: a comparative approach in glacial environment. Int J Appl Earth Obs Geoinf. 2015;38:150-63.

63. Li J, Sheng Y. An automated scheme for glacial lake dynamics mapping using Landsat imagery and digital elevation models: a case study in the Himalayas. Int J Remote Sens. 2012;33(16):5194-213.

64. Robson BA, Nuth C, Dahl SO, Hölbling D, Strozzi T, Nielsen PR. Automated classification of debris-covered glaciers combining optical, SAR and topographic data in an object-based environment. Remote Sens Environ. 2015;170:372-87.

65. Roy D, Wulder M, Loveland T, Woodcock C, Allen R, Anderson M, et al. Landsat-8: Science and product vision for terrestrial global change research. Remote Sens Environ. 2014;145:154-72. 
66. Salerno F, Thakuri S, Agata CD, Smiraglia C, Manfredi CE, Viviano G, Tartari G. Glacial Lake distribution in the Mount Everst region: Uncertanity of measurement and conditions of formation. Glob Planet Change. 2012;92:30-9.

67. Gao BC. NDWI-A normalized difference water index for remote sesning of vegetation liquid water from space. Remote Sens Environ. 1996;58(3):257-66.

68. Gardelle J, Arnaud Y, Berthier E. Contrasted evolution of glacial lakes along the Hindu Kush Himalaya mountain range between 1990 and 2009. Glob Planet Change. 2011;75(1-2):47-55.

69. Worni R, Huggel C, Stoffel M. Glacier Lakes in the Indian Himalayas- From area-wide glacial lake inventory to on-site and modeling based rsik assessment of critical glacial lakes. Sci Total Environ. 2013;468:71-84.

70. McFeeters SK. The use of the Normalized Difference Water Index (NDWI) in the delineation of open water features. Int J Remote Sens. 1996;17(7):1425-32.

71. Murtaza KO, Romshoo SA. Recent glacier changes in the Kashmir Himalayas, India. Geocarto Int. 2017;2:188-205.

72. Romshoo SA, Fayaz M, Meraj G, Bahuguna I. Satellite-observed glacier recession in the Kashmir Himalaya, India, from 1980-2018. Environ Monit Assess. 2020;192(9):1-17.

73. Bhambri R, Mehta M, Dobhal DP, Gupta AK. Glacier lake inventory of Uttarakhand. Dehradun: Wadia Institute of Himalayan Geology; 2015.

74. Wang X, Guo X, Yang C, Liu Q, Wei J, Zhang Y, et al. Glacial lake inventory of high-mountain Asia in 1990 and 2018 derived from Landsat images. Earth Syst Sci Data. 2020;12(3):2169-82.

75. Scheffers AM, Kelletat DH. Lakes of the world with google earth: understanding our environment, vol. 16. Berlin: Springer; 2016.

76. Cao XC, Liu ZZ, Li WS. Glacial lake mapping and analysis of the potentially dangerous glacial lakes before Nepal 425 Earthquake in 2015. J Glaciol Geocryol. 2016;38(3):573-83.

77. Mool PK, Maskey PR, Koirala A, Joshi SP, Wu L, Shrestha AB, et al. Glacial lakes and glacial lake outburst floods in Nepal. Lalitpur: Icimod; 2011. p. 1-109.

78. Ageta Y, Iwata S, Yabuki H, Naito N, Sakai A, Narama CH, Karma T. Expansion of glacier lakes in recent decades in the Bhutan Himalayas. Wallingford: IAHS Publication; 2000. p. 165-76.

79. Shafiq MU, Islam ZU, Bhat IA, Ahmed P. Spatio-temporal behaviour of Nehnar Glacier from 1962 to 2017, Jhelum basin, Kashmir Himalayas, India. Phys Geogr. 2020;41(6):517-36.

80. Che T, Xiao L, Liou YA. Changes in glaciers and glacial lakes and the identification of dangerous glacial lakes in the Pumqu River Basin, Xizang (Tibet). Adv Meteorol. 2014. https://doi.org/10.1155/2014/903709.

81. Aggarwal A, Jain SK, Lohani AK, Jain N. Glacial lake outburst flood risk assessment using combined approaches of remote sensing, GIS and dam break modelling. Geomat Nat Haz Risk. 2016;7(1):18-36.

82. Ahmad ST, Ahmed R, Wani GF, Sharma P, Ahmed P. Glacier changes in Sind basin (1990-2018 of North-western Himalayas using earth observation data). Model Earth Syst Environ. 2021. https://doi.org/10.1007/s40808-021-01246-w.

83. Chevutri A, Dimri AP, Thayyen RJ. Climate change over Leh (Ladakh), India. Theor Appl Climatol. 2018;131(1-2):531-45.

84. Clague JJ, Evans SG. Formation and failure of natural dams in the Canadian Cordillera, vol. 464. Ottawa: Geological Survey of Canada; 1994.

85. Shafiq MU, Rasool R, Ahmed P, Dimri AP. Temperature and precipitation trends in Kashmir Valley, north western Himalayas. Theor Appl Climatol. 2019;135(1-2):293-304.

86. Dimri AP, Dash SK. Wintertime climatic trends in the western Himalaya. Clim Change. 2012;111(3-4):775-800.

87. Jeelani G, Deshpande RD, Shah RA, Hassan W. Influence of southwest monsoons in the Kashmir Valley, western Himalayas. Isot Environ Health Stud. 2017;53(4):400-12.

88. Prasad AK, Yang KH, El-Askary HM, Kafatos M. Melting of major Glaciers in the western Himalayas: evidence of climatic changes from long term MSU derived tropospheric temperature trend (1979-2008). Ann Geophys. 2009;27(12):4505-19.

89. Kang S, Xu Y, You Q, Flugel WA, Pepin N, Yao T. Review of climate and cryosphereic change in the Tibetan Plataeu. Environ Res Lett. 2010;5(1):015101.

90. Shukla A, Garg PK, Srivastava S. Evolution of glacial and high-altitude lakes in the Sikkim, Eastern Himalaya over the past four decades (1975-2017). Front Environ Sci. 2018;6:81.

91. Wang X, Zhou A, Sun Z. Spatial and temporal dynamics of lakes in Nam Co Basin, 1991-2011. J Earth Sci. 2016;27(1):130-8.

92. Prakash C, Nagarajan R. Glacial lake changes and outburst flood hazard in Chandra basin, North-Western Indian Himalaya. Geomat Nat Haz Risk. 2018;9(1):337-55.

93. Begam S, Sen D. Mapping of moraine dammed glacial lakes and assessment of their areal changes in the central and eastern Himalayas using satellite data. J Mt Sci. 2019;16(1):77-94.

Publisher's Note Springer Nature remains neutral with regard to jurisdictional claims in published maps and institutional affiliations. 